\title{
CONGLOMERATE MANAGEMENT OF ENTERPRISE AS SOCIO-ECONOMIC SYSTEM
}

\author{
Maryna Spivak ${ }^{1}$ \\ National Academy of Internal Affairs of Ukraine, Ukraine \\ Olesia Khokhuliak², Anastasiya Inshyna ${ }^{3}$ \\ Nova Kakhovka Institute of Humanities, \\ Open International University of Human Development "Ukraine", Ukraine
}

\begin{abstract}
In modern conditions of political, economic, and social globalization, it is difficult to overestimate for Ukraine the need for research and introduction of new forms of enterprise management. World tendencies of the interaction of business elements are characterized by decentralized integration, in which, preserving their legal and industrial identity, small and medium business is united in economic communities, trying to withstand large monopolistic associations. The modern business environment in the dual model at one pole is represented by corporations, TNCs, MNCs, and at the other pole - by free entrepreneurs (freelancers), the number of which is steadily growing. The contradictions and shortcomings of both poles are harmonized by the intra-national integration of economic interests. New business models of economic interaction arise that require new models and forms of management, require the creation of new, adaptive formats of business interaction that involves the mandatory inclusion of standards for sustainable development (economic, environmental, and social mechanism). Such a new form of management, in our view, can be an innovative model of conglomerate management, which implies not only conglomerate mergers and acquisitions of corporations but also new mechanisms for interaction of small business structures of different economic and sectoral orientation. The terminology and the theoretical basis for studying the conglomerate as a socio-economic system that includes the basic phrase "socio-economic system" were defined. Such a form of organization of socio-economic systems, which would consolidate high competitive advantages, innovative orientation, and significant expansive potential, is proposed. On the basis of generalization of the corresponding theoretical provisions and revealed peculiarities of the formation of spatially localized systems, we assumed that emerging as local "points" of economic growth zones, individual elements or subsystems of enterprises are transformed into territorial production complexes (hereinafter abbreviated as TPC), and then - by implementing the missing infrastructure and institutional components into a variety of cluster forms, into conglomerates.
\end{abstract}

As a result of the research, the following scientific substantiations and conclusions are formulated:

1. For the first time, the term "conglomerate management" was proposed as the aggregate interaction of enterprises united into a spatially localized socio-economic system and a methodological approach to managing such complex structures.

2. A terminology for investigating the purposeful transformation of society and the economy into an additive socioeconomic system is developed. Such studies are especially relevant for the modern domestic economy, which contains controversial characteristics of the deterministic and nondeterministic economic model, as well as poorly predicted agglomerate and synergistic effects.

3. A model for organizing and managing conglomerates of a new type is formed. The architecture of the conglomerate enterprise management model as an element of a socio-economic system with an innovative basis as a priority for the dynamic development of a conglomerate is proposed.

\footnotetext{
Corresponding author:

${ }^{1}$ Department of Administrative Law and Procedure, National Academy of Internal Affairs of Ukraine.

E-mail: rainbow.m84@gmail.com

${ }^{2}$ Department of Management and Administration, Nova Kakhovka Institute of Humanities,

Open International University of Human Development "Ukraine".

E-mail: oleolex.22@gmail.com

${ }^{3}$ Department of Legal Sciences, Nova Kakhovka Institute of Humanities,

Open International University of Human Development "Ukraine".

E-mail: alex0674682444@gmail.com
} 
4. We also find it economically sound to create a model of developing the strategic potential of an enterprise as an open socio-economic system, to use the mathematical apparatus of studying models of the fractal type that describes the evolution of a modelled system of fractal objects.

5. A parametric characteristic of the formation of a deterministic model of conglomerate control of a fractal type as a socio-economic system was developed and brought to the form of an economic-mathematical model.

Key words: complex structured enterprises, socio-economic system, economic growth zone, territorial production complexes, conglomerate, deterministic model, conglomerate management.

JEL Classification: G30, M19, O20, C22

\section{Introduction}

The trajectory and speed of economic and social processes, changes that occur in the macroeconomic space, naturally and sometimes simultaneously create the necessary prerequisites for the emergence and development of modern tools, methods, and models for developing the strategic potential of enterprises, taking into account global strategies for balanced development. The more intensive the influence of global exogenous factors, the more urgent the problem of creating and implementing a modern additive management model that will allow setting regulated vectors for balanced development, which is especially important for complex structured organizations, which include corporations and concerns.

The existing economic and social conditions do not raise doubts that large complex structured organizations are systems of an open type that are in a state of constant dynamic fluctuation and their integrity is determined by a complex of internal and external links and a way of interacting constituent elements.

In modern conditions of political, economic, and social globalization, it is difficult to overestimate for Ukraine the need for research and the introduction of new forms of enterprise management. World tendencies of the interaction of business elements are characterized by decentralized integration, in which, preserving their legal and industrial identity, small and medium-sized business unites into economic communities, trying to withstand large monopolistic associations. The modern business environment in the dual model at one pole is represented by corporations, TNCs, MNCs, and at the other pole by free entrepreneurs (freelancers), the number of which is steadily growing. The contradictions and shortcomings of both poles are harmonized by the international integration of economic interests. New business models of economic interaction arise that require new models and forms of management, require the creation of new, adaptive formats of business interaction that involves the mandatory inclusion of standards for sustainable development (economic, environmental, and social mechanism). Such a new form of management, in our opinion, can be an innovative model of conglomerate management, which implies not only conglomerate mergers and acquisitions of corporations but also new mechanisms for interaction of small business structures of different economic and sectoral orientation. Classical mechanisms of interaction are transformed into modern methods and technologies of management combining globalization information trends with strict economic and legal conditions for survival in the market, regardless of the size of the company.

Defining the theoretical basis for studying the conglomerate as a socio-economic system, it is necessary to determine the terminological apparatus, which in this case includes the basic phrase "social and economic system." In this concept, the three largest scientific categories are synthesized: the system as a set of subsystems; economic system (as a subsystem); social system (as a subsystem).

It is expedient to characterize the scientific category "system" by using the general theory of systems; the main representatives of the scientific school are such scientists as M. Mesarovich (Mesarovich, 1978 (Ed)), L.Zade (Zade, 1974), R. Akoff (Akoff, 1972), A. Uemov (Uemov, 1978), R. Kálmán (R. Kálmán, P. Falb, M. Arbib, 2004), S. Beer (Beer S., 2010), I. Prigozhin (Prigozhin I., 1986), and others. Continuous research of systems leads to the discovery of new properties and principles of their functioning, development, and transformations. This makes it possible to apply new tools, methods, and approaches to studying systems with different properties.

To study the economic system, from the point of view of research practice, it seems possible to apply the socio-economic approach. It consists in the fact that the studied object is an economy; it is viewed as a complexly organized socio-economic system. Within the framework of such a holistic system, diverse socioeconomic relations are realized. This approach allows objectively considering and analysing the system of views that form these relations. Its application allows identifying the possibilities of not only individual subsystems (spheres) but also integral factors of combining these subsystems, which by themselves, by simple addition, are not manifested. As a part of the socio-economic approach, such scientists as P. Bourdieu (Bourdieu, 2001), M. Abolafia (Abolafia, 1998), V. Inozemtsev (Inozemcev, 2005), V. Martsinkevich (Martsinkevich, 2003), M. Weber (Weber, 1978), L. Robbins (Robbins, 1993), K. Polanyi (Polanyi, 2001) consider the economy not simply as a set of 
specific actions but as a set of economic and noneconomic actions (often referred to as "social actions" for the purpose of simplicity). We use this statement as a theoretical basis for studying the object of investigation.

Proceeding from a review of existing ideas about socio-economic systems, it is obvious that today in the scientific literature an established concept of it as a kind of integrity has not yet formulated. The main attention is paid primarily to the study of socio-economic relations implemented within the system. Today, not only economists but also representatives of related sciences economic sociology, political science, and psychology are actively engaged in such studies. Moreover, outside the area of their study, the fact remains that the form in which these relations are realized is a socio-economic system as a way of existence of content (socio-economic relations), inseparable from it and serving as its expression. In this connection, there is a need to study, analyse, and supplement the conceptual framework that can characterize an enterprise as a socio-economic system of a conglomerate. Distinguish the elements of the subsystem as an objectively necessary environment for functioning that can ensure the development of the enterprise's economy, social and economic relations inside and outside its boundaries, and will affect the structure of the entire social and economic system of the conglomerate, i.e. to form new methodological approaches to the concept of managing a set of interacting enterprises as a conglomerate socio-economic system.

The purpose of the article is to systematize scientific categories and highlight the modern economic definition of "conglomerate enterprise management", which will allow identifying promising directions for the formation of a complex structured innovation model of conglomerate management as a socio-economic system.

\section{The methodology of research}

Using the postulates of systemic and socio-economic approaches, studies of the interconnection and interaction of economic and social action, it can be argued that the socio-economic system is a complex system, in which man is the central element, functions as the main participant in reproduction and as the main factor and stimulus for developing the whole system. Thus, the object of research expands from the narrow framework of a simple object - the economic system to a supercomplex object - the socio-economic system.

Using the terminology of economic synergetics (Delokarov, 2000; Dobronravova, 1990; Sinergetike 30 let, 2000; Shvets, 2007), the socio-economic system should be viewed not so much as a mode of production, a market or a set of interacting economic entities and objects, but as a complex system prone to self-organization.

The formation of the economy of a new type, the establishment of institutions, and the formation of new adaptive and modern models of the operation of enterprises of different scales and legal forms of ownership require a radical change in the vision and approaches to the spatial-organizational allocation of elements of socio-economic systems.

In this connection, it becomes necessary to define such a form of organization of socio-economic systems that would consolidate high competitive advantages, innovative orientation, and significant expansive potential.

In order to study the laws of development and trends of formation, we propose to consider the socio-economic system in the form of spatially localized systems, for which the gradual change of the existing institutional forms, the formation of complex diversified structures of integration interaction can provide an evolutionary transformation of the economic, social, and technological modes of the economy (Kochubej, 2005; Cheshkov, 1999).

We propose a postulate that enterprises as business structures of a new format are integrated into conglomerates, and thus retain the advantages and capabilities of a dynamic, self-organizing system that seamlessly interacts with elements of other systems, business structures, social and financial institutions.

On the basis of generalization of the corresponding theoretical provisions and the revealed peculiarities of the formation of spatially localized systems, we assume that emerging as local "points" of economic growth zones, individual elements or subsystems are transformed into territorial production complexes (hereinafter - TPC) and then - by implementing the missing infrastructure and institutional components, into a variety of cluster forms, the architecture of which is presented in Figure 1 (formed on the basis of (Merkulova, 2014; Mykhajlenko, 2006; Skripnichenko, 2011).

The experience of the formation of conglomerates in developed countries shows that the zones of economic growth are subsequently formed into separate structural units of the TPC, and this testifies to the need to build a fundamentally new system of regional, territorial, and corporate governance that can ensure the manifestation of agglomerate effects to meet the growing needs, the economy of the enterprise, and its transition into the form of a conglomerate. This, in turn, will affect the socioeconomic development of the region (Kalynychenko, 2010; Melnik, 2005; Tarasevich, 2005).

At the same time, the author proposes to use the postulates of the theory of fractals as a methodological basis for solving multifaceted problems of regulating the development of the system and the mechanisms for its self-organization, which makes it possible to carry out studies of the evolutionary process of transforming territorial "points" into zones of economic growth, and then transforming them into a TPC (Miziuk, 2006).

The formation of adaptive development conditions will allow the territorial-production complexes to create various forms based on conglomerate mechanisms, with the subsequent creation of a unique locally integrated socio-economic system (Miziuk, 2006). 


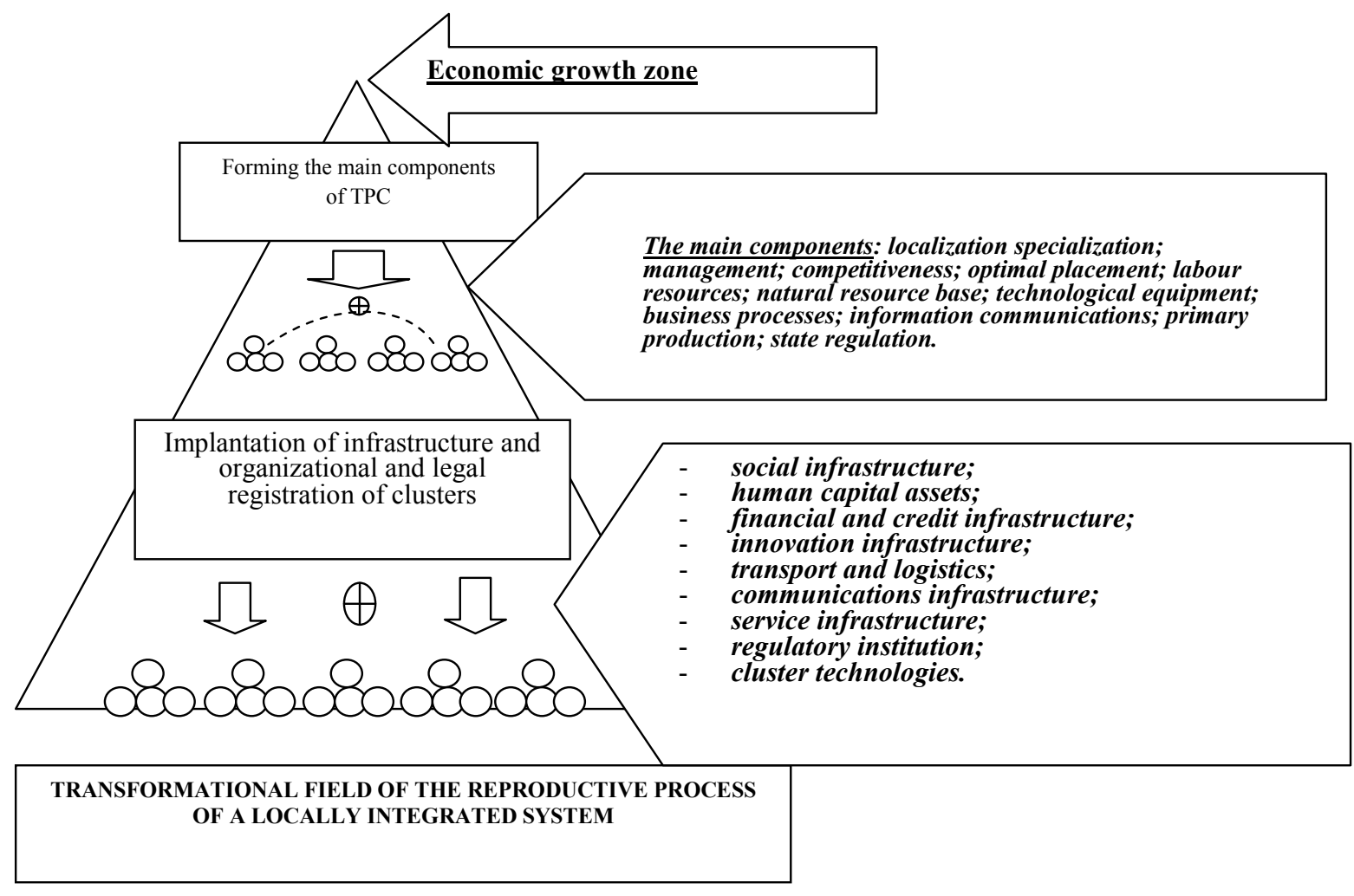

Figure 1. The architecture of the model of conglomerate enterprise management as an element of the socio-economic system Source: (the author's development)

\section{Results and discussion}

Applied methods for assessing socio-economic transformations do not fully meet modern challenges since they usually do not contain methods for interpreting the results of research. The absence of a full theoretical elaboration and revealing the high importance of the problem, creating points of economic growth allows actualizing this issue within the framework of the proposed study.

In the process of generating new points of economic growth, it is necessary to fulfil the following criterial requirements: complexity, efficiency, and social orientation, which will ensure a safe and balanced development of the economy of the conglomerate. In favourable conditions, the points of economic growth are transformed into zones of economic growth (Blonska, 2010; Tarasevich, 2013).

First of all, such points of economic growth should provide for a comprehensive regional development since the goal-setting object is all sectors and spheres of the region's activities, as well as the economic and social processes within it that may not have clearly defined boundaries of the socio-economic system, nevertheless, possess all its attributes.

The criterion of integral efficiency is fundamental for generating points of economic growth since the use of the available financial and resource potential should ensure the growth of investment volume, the growth of the economy's assets (capitalization of markets: industrial, stock, commodity) and, as a result, maximum cost effectiveness and profitability of resources. Social orientation of points of economic growth manifests itself in such categories as life expectancy and health status, level and lifestyle of the population. The "social standards of the quality of life" adopted in the country make it possible to determine the feasibility of developing new approaches to the management of spatially localized systems. The implementation of key elements of the Concept of Sustainable Development, which Ukraine joined after the Rio Summit (2012), must be supplemented with the requirements:

1. Improved scientific and methodological tools, directions of innovative development of enterprises and conglomerate;

2. Socio-economic parameters specific to the Ukrainian economy, in particular, targeted reduction in the level of corruption.

We propose to introduce a set of indicators given and grouped by indicator vectors as a basis for the economic and mathematical modelling of the deterministic conglomerate management model of the fractal type (Table 1, Figure 2).

In the process of development, there were studied (Osnovymodelirovanijasystem,2012; Urmancev, 1988). Some analysts believe that the Ukrainian economic development model refers to nondeterministic, that is, 
under certain input parameters, the initial result is more uncertain, stochastic, even probabilistic.

Experts in the field of macroeconomics argue that the economic model of the national economy as an object cannot be represented in the form of a classical economic-mathematical model since we are dealing with non-linearity (multivariance of development paths and the need for choice) and the indeterminacy, chaos, and irreversibility of evolutionary processes. We are convinced of the opposite and we consider the model of the Ukrainian economy as deterministic provided a correct information base, qualitative methodological tools, and effective goal-setting.

Parameters of scientific and methodological terminology (HMT group) with positive vector dynamics actually reflect the direction of social and economic transformations taking into account conglomerate synergies and implantation of cluster infrastructure. At the same time, we consider the level of implementation of the cluster infrastructure as a single-valued correlation of this parameter with the effective corporate and innovative components of the economy as a whole. The conglomerate management model (MKY) describing the system $V\left(x_{1}, x_{2}, \ldots, x_{n} ; R\right)$ has the form:

$\mathrm{MKY}=\left(\mathrm{Z}_{1}, \mathrm{Z}_{2}, \ldots, \mathrm{Z}_{\mathrm{m}} ; \mathrm{Q}\right)$,

Where: $Z_{i} \in Z, i=1,2, \ldots, n$

$\mathrm{Q}$ - set of relations over X - the set of incoming parameters, outgoing states of the economic system,

$\mathrm{Z}$ - set of economic relations, representations of elements and subsets of X (Figure 2).

$Q(V x)$ - sets of indicator vectors (SMT, DI, EI, FI, SI, ID, PFAC)

Table 1

Parameters of formation of a deterministic model of conglomerate management of a fractal type

\begin{tabular}{|c|c|c|}
\hline Indicator vectors $(\mathrm{V})$ & $\begin{array}{c}\text { Symbols } \\
\text { in the model, } \\
\text { vector direction }\end{array}$ & Estimated figures $(\mathrm{Z})$ \\
\hline $\begin{array}{l}\text { Scientific-methodological } \\
\text { terms }\end{array}$ & 介 $\mathrm{sMT}$ & $\begin{array}{l}\text { Level of conglomerate economy } \\
\text { Level of conglomerate synergy } \\
\text { Level of implementation of the cluster infrastructure }\end{array}$ \\
\hline Demographic indices & DI & $\begin{array}{l}\text { Number of the resident population (thousand people) } \\
\text { Density of population (people/sq. km) } \\
\text { Average number of employees (people) } \\
\text { Rate of natural increase, infant mortality } \\
\text { Share of older people in the total population } \\
\text { Migration balance of the region and country }\end{array}$ \\
\hline Economic indicators & EI & $\begin{array}{l}\text { Number of enterprises registered in the state register of the region (units) } \\
\text { Volume of shipped goods, performed works and services of its own production, } \\
\text { and organizations for "pure" types of economic activity per capita (thousand UAH). } \\
\text { Volume of real investments in fixed assets per one enterprise (thousand UAH) } \\
\text { Volume of housing stock in the region per capita (sq. m) } \\
\text { Volume of gross agricultural output per capita (thousand UAH) } \\
\text { Volume of retail trade through all channels of sales in the region per capita (thousand UAH) }\end{array}$ \\
\hline Finance indicators & FI & $\begin{array}{l}\text { Capitalization of markets (industrial, stock, commodity) } \\
\text { The balanced financial result per one enterprise (thousand UAH); } \\
\text { Aggregate income per capita - wages, taking into account the purchasing power parity - } \\
\text { the cost of the consumer basket (thousand UAH) } \\
\text { Deficit (surplus) of the regional budget, taking into account the parity of the country's } \\
\text { budget (thousand UAH) }\end{array}$ \\
\hline Social indicators & SI & $\begin{array}{l}\text { Number of employees } \\
\text { Amount of social payments } \\
\text { Level of money savings of the population, etc. } \\
\text { Level of consumption of basic foodstuffs } \\
\text { Level of health protection, level of education } \\
\text { Level of provision with various material goods (housing, communications, own cars, } \\
\text { information means) }\end{array}$ \\
\hline Innovative development & ПI ID & $\begin{array}{l}\text { Volume of investment in infrastructure } \\
\text { Volume of investments in new developments and technologies } \\
\text { Number of new enterprises with innovative technologies } \\
\text { Number of clusters with a level of profitability higher than the industry average }\end{array}$ \\
\hline $\begin{array}{l}\text { Parameters (level) of fight } \\
\text { against corruption }\end{array}$ & $\Uparrow_{\text {PFAC }}$ & $\begin{array}{l}\text { Quantitative rotation of managerial personnel in the state segment } \\
\text { Ukraine's position in international corruption ratings } \\
\text { Socio-information anti-corruption propaganda in the media } \\
\text { Relevant legislative framework and anti-corruption monitoring system }\end{array}$ \\
\hline
\end{tabular}




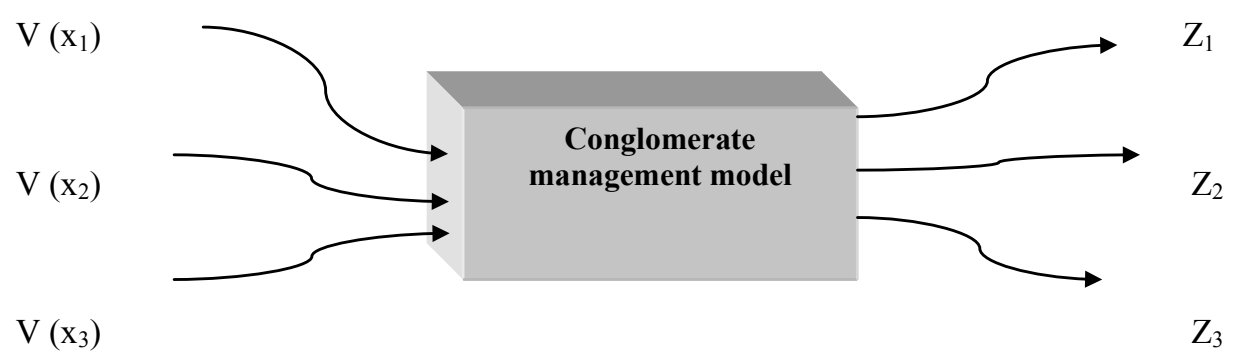

$\mathrm{Z}$ - sets of economic relations

Figure 2. Formation of the deterministic model of conglomerate management of fractal type (MKY)

We also offer to maximize the presented set of parameters (Table 1) $\mathrm{Z}_{1-\mathrm{m}}$ in vector dynamics, as positive characteristics of the macroeconomic development of the conglomerate economy. Then, the economicmathematical model of conglomerate synergetics will look like:

$\mathrm{n} \mathrm{m}$

$$
\text { ИР МКУ }=\sum \sum \mathrm{x}_{\mathrm{i}} \mathrm{x}_{\mathrm{j}} \mathrm{V}_{\mathrm{ij}} \mathrm{z}_{\mathrm{i}} \mathrm{z}_{\mathrm{j}} \rightarrow \max
$$$$
\mathrm{x}=\mathrm{l} \mathrm{z}=1
$$

The problem (2) is solved by the gradient projection method or the method of possible directions. The optimal ratio of economic development indicators can also be determined using the Solver optimizer of Microsoft Excel.

\section{Conclusions}

As a result of the research, the following scientific substantiations and conclusions are formulated:

1. For the first time, the term "conglomerate management" was proposed as the aggregate interaction of enterprises united into a spatially localized socioeconomic system and a methodological approach to managing such complex structures.

2. A terminology for investigating the purposeful transformation of society and the economy into an additive socio-economic system is developed.
Such studies are especially relevant for the modern domestic economy, which contains controversial characteristics of the deterministic and nondeterministic economic model, as well as poorly predicted agglomerate and synergistic effects.

3. A model for organizing and managing conglomerates of a new type is formed. The architecture of the conglomerate enterprise management model as an element of a socio-economic system with an innovative basis as a priority for the dynamic development of a conglomerate is proposed.

4. We also find it economically sound to create a model of developing the strategic potential of an enterprise as an open socio-economic system, to use the mathematical apparatus of studying models of the fractal type that describes the evolution of a modelled system of fractal objects.

5. A parametric characteristic of the formation of a deterministic model of conglomerate control of a fractal type as a socio-economic system was developed and brought to the form of an economic-mathematical model.

The author sees further prospects in studies of latent symptoms that affect the phased formation, firstly, of the zones of economic growth, and then - the TPC, and the transformation of conglomerates into a socio-economic system containing signs of a universal economy.

\section{References:}

Akoff R. (1972). Planirovanie v bolshih jekonomicheskih sistemah: per. s angl. [Planning for large economic systems]. Moscow: Sovetskoe radio. (in Russian)

Blonska V.I. (2010). Vdoskonalennia metodyky analizu stratehichnoho potentsialu pidpryiemstva [Improved methods of analyzing potential strategic enterprises]. Naukovyj visnyk NLTU Ukrainy. 20.1, pp. 171-175. (in Ukrainian)

Beer S. (2010). Kibernetika i menedzhment [Cybernetics and Management]. Moscow: KomKniga (in Ukrainian) Bourdieu P. (2001). Prakticheskij smysl [The practical meaning]. St. Petersburg: Aletejja. (in Russian)

Delokarov K.H. (2000). Sistemnaja paradigma sovremennoj nauki i sinergetika [System paradigm of modern science and synergy]. Obshhestvennye nauki i sovremennost - Social Sciences and Modernity. 6, pp. 111-112. (in Russian)

Dobronravova S. (1990). Sinergetika: stanovlenie nelinejnogo myshlenija [Synergetics: the establishment of nonlinear thinking]. Kyiv: Libid. (in Russian)

Zade L.A. (1974). Osnovy novogo podhoda $\mathrm{k}$ analizu slozhnyh sistem i processov prinjatija reshenij. - V kn.: Matematika segodnja [A new approach to the analysis of complex systems and decision-making processes]. Moscow: Znanie. (in Russian) 
Inozemtsev V.L. (2005). Postindustrialnoe obshhestvo kak teoreticheskaja konstrukcija [Post-industrial society as a theoretical construct]. Socialno-jekonomicheskie problemy informacionnogo obshhestva - [Socio-economic issues of the information society]. L.G. Melnika (Ed). Sumy: Universitetskaja kniga. (in Ukrainian)

Kalman R., P. Falb, M. Arbib (2004). Ocherki po matematicheskoj teorii sistem: per. s angl. [Essays on mathematical systems theory]. Moscow: Editorial URSS. (in Russian)

Kalynychenko Yu. (2010). Stratehichnyj rozvytok pidpryiemstva: teoretychni ta praktychni aspekty [Strategic development of the enterprise: theoretical and practical aspects]. Halytskyj ekonomichnyj visnyk - Galician Economic Bulletin, 4(29), 106-115. Retrieved from: http://elartu.tntu.edu.ua/bitstream/123456789/866/2/GEB_2010_ v29_No4-Ju_Kalynichenko-Strategic_development_of_the_enterprise_theoretical_106.pdf (in Russian)

Kochubej N.V., Kochubej R.V. (2005). Sinergeticheskaja metodologija issledovanija socialno - jekonomicheskih sistem [Synergistic research methodology of socio-economic systems]. Socialno-jekonomicheskie problemy informacionnogo obshhestva-Socio-economicissues of the information society. L.G. Melnika (Ed). Sumy: Universitetskaja kniga. (in Ukrainian)

Lekcija: Osnovy modelirovanija sistem [Lecture: Basics of system simulation] (n.d.) life-prog.ru. Retrieved from http://life-prog.ru/1_10724_lektsiya-osnovi-modelirovaniya-sistem.html (in Russian)

Martsinkevich V. (2003). Jekonomicheskij mjejnstrim i sovremennoe vosproizvodstvo [Economic mainstream and modern reproduction]. Mirovaja jekonomika i mezhdunarodnye otnoshenija - World Economy and International Relations, 2, 36-41. (in Russian)

Melnik L.G. (2005). Predposylki formirovanija informacionnogo obshhestva [Background of the information society]. Socialno-jekonomicheskie problemy informacionnogo obshhestva - Socio-economic issues of the information society. L.G. Melnika (Ed). Sumy: Universitetskaja kniga. (in Ukrainian)

Merkulova E.A. (2014). Metodicheskij instrumentarij vyjavlenija tochek jekonomicheskogo rosta $\mathrm{v}$ regione [Methodical toolkit to identify points of economic growth in the region]. Socialno-jekonomicheskie javlenija $\mathrm{i}$ process Socio-economic phenomena and processes, 10 (9). Retrieved from: http://cyberleninka.ru/article/n/ metodicheskiy-instrumentariy-vyyavleniya-tochek-ekonomicheskogo-rosta-v-regione (in Russian)

Mesarovich M. (1978 (Ed)). Obshhaja teorija sistem: matematicheskie osnovy [General Systems Theory: mathematical foundations]. Moscow: Mir. (in Russian)

Mykhajlenko M.M. (2006). Stratehichnyj potentsial pidpryiemstva iak obiekt upravlinnia: avtoref. dys. na zdobuttia nauk. stupenia kand. ekon. nauk [The strategic potential of the company as the object management]. Extended abstract of candidate's thesis. Kyiv: Kyiv. (in Ukrainian)

Miziuk B.M. (2006). Stratehichne upravlinnia pidpryiemstvom: pidruchnyk [Strategic Enterprise Management: textbook]. Lviv: «Mahnoliia Plius». (in Ukrainian)

Prigozhin I. (1986). Porjadok iz haosa. Novyj dialog cheloveka s prirodoj [Order out of chaos. The new dialogue of man with nature]. Moscow: Progress. (in Russian)

Robbins L. (1993). Predmet jekonomicheskoj nauki [The subject of economic science]. Thesis - Thesis, 1(1), 18-19. (in Russian)

Sinergetike - 30 let. (2000) Intervju s professorom G. Hakenom [Synergetics - 30 years. Interview with Prof. H. Haken]. Voprosy filosofii - Questions about philosophy, 3, 54. (in Russian)

Skripnichenko Ju.S. (2011). Subklaster kak forma razvitija prostranstvenno-lokalizovannyh sistem agrarnogo sektora jekonomiki region [Subclusters as a form of spatially-localized systems of the agrarian sector of the economy region]. Extended abstract of candidate's thesis. Retrieved from: http://economy-lib.com/subklaster-kak-formarazvitiya-prostranstvenno-lokalizovannyh-sistem-agrarnogo-sektora-ekonomiki-regiona (in Russian)

Tarasevich V.N. (2005). Postindustrializm postneklassicheskoj nauki [Post-industrialism postnonclassical science]. Socialno-jekonomicheskie problemy informacionnogo obshhestva - Socio-economic issues of the information society. L.G. Melnika (Ed). Sumy: Universitetskaja kniga. (in Russian)

Tarasevich V.N. (2013). Fundamentalnaja jekonomicheskaja nauka XXI veka: orientiry i vektory peremen [The fundamental economic science of the XXI century: Landmarks and vectors of change]. Visnik Kiivskogo nacionalnogo universitetu im. Tarasa Shevchenka. Serija: Ekonomika - Bulletin Kyivskoho National University. Taras Shevchenko. Series: Economics, 146. Retrieved from: http://cyberleninka.ru/article/n/fundamentalnayaekonomicheskaya-nauka-xxi-veka-orientiry-i-vektory-peremen (in Russian)

Uemov A.I. (1978). Sistemnyj podhod i obshhaja teorija sistem [System approach and general systems theory], Moscow: Mysl. (in Russian)

Urmancev Ju.A. (1988). Jevoljucionika ili obshhaja teorija razvitija sistem prirody, obshhestva i myshlenija [Evolution or the general theory of systems of nature, society and mindset]. Moscow: Pushhino: ONTI NCBI AN SSSR. (in Russian)

Cheshkov M.A. (1999). Sinergetika: za i protiv haosa (zametki o nauke jepohi globalnoj smuty) [Synergetics: the pros and cons of chaos (notes on the science of the era of global turmoil)]. Obshhestvennye nauki $\mathrm{i}$ sovremennost. - Social Sciences and Modernity, 6, 138-139. (in Russian)

Abolafia M. (1998). Markets as Cultures: An Ethnographic Approach. Callon, M. (Ed.) The Law of Markets. Oxford: Blackwell. (in English)

Polanyi K. (2001). The Great Transformation. Boston: Beacon Press. (in English)

Weber M. (1978). Economy and Society: Vol. I. Berkeley: University of California Press. (in English) 